\title{
TUGAS MAKALAH
}

\section{ANALISIS KEBUTUHAN SARANA DAN PRASARANA PERMUKIMAN \\ PADA KECAMATAN MANGKUTANA KABUPATEN LUWU TIMUR}

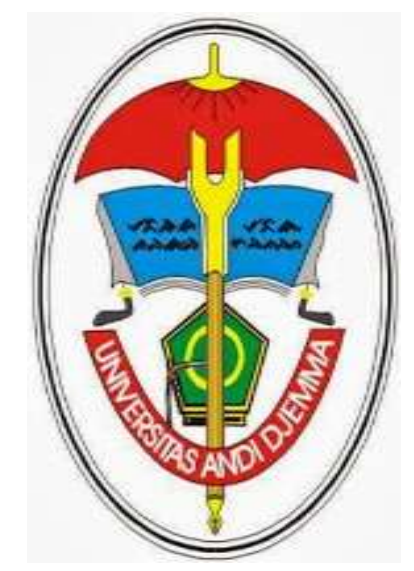

DI SUSUN OLEH:

KELOMPOK 7

ARNOL BATARA TAU

SUNARDI DJULAEMI

AIDIL

DANDI
17.023.22.201.010

17.023.22.201.027

17.023.22.201.030

17.023.22.201.040

\section{PROGRAM STUDI SIPIL}

FAKULTAS TEKNIK

UNIVERSITAS ANDI DJEMMA PALOPO 


\section{KATA PENGANTAR}

Puji syukur penulis penjatkan kehadirat Alloh SWT, yang atas rahmat-Nya maka penulis dapat menyelesaikan penyusunan makalah "Perencanaan wilayah dan Kota”. Makalah ini merupakan salah satu tugas dari dosen mata kuliah pengantar perencanaan wilayah dan kota.

Dalam Penulisan makalah ini penulis merasa masih banyak kekurangankekurangan baik pada teknis penulisan maupun materi, mengingat akan kemampuan yang dimiliki penulis. Untuk itu kritik dan saran dari semua pihak sangat penulis harapkan demi penyempurnaan pembuatan makalah ini.

Secara khusus penulis menyampaikan ucapan terima kasih kepada dosen mata kuliah perencanaan wilayah dan kota, beserta teman-teman yang telah berpartisipasi dalam penyelesaian makalah ini dan bantuan serta pengertian yang besar kepada penulis, baik selama mengikuti perkuliahan maupun dalam menyelesaikan makalah ini.

Akhirnya penulis berharap semoga Allah memberikan imbalan yang setimpal pada mereka yang telah memberikan bantuan, dan dapat menjadikan semua bantuan ini sebagai ibadah, Amiin Yaa Robbal 'Alamin

Palopo, Januari 2022

Penulis 


\section{DAFTAR ISI}

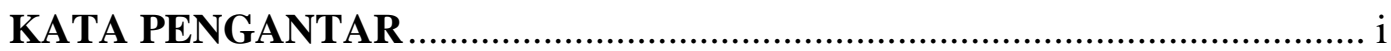

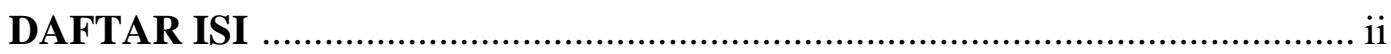

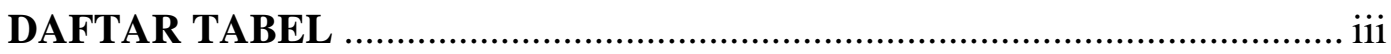

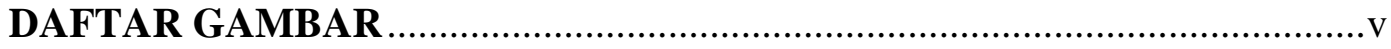

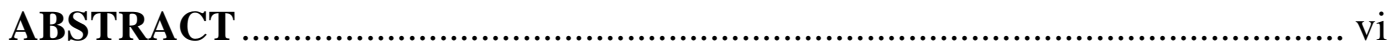

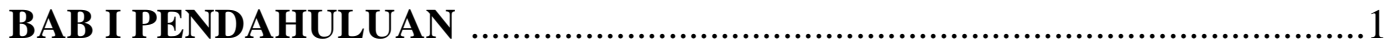

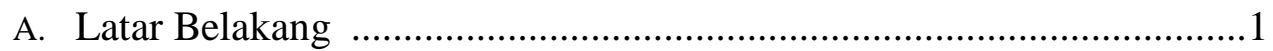

B. Rumusan Masalah ..................................................................................2

C. Tujuan Penulisan ..........................................................................2

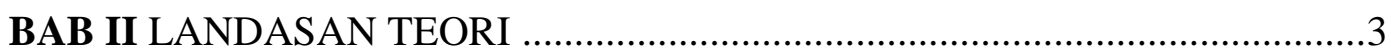

A. Definisi Sarana Dan Prasarana ............................................................. 3

B. Standar Sarana Dan Prasarana .............................................................4

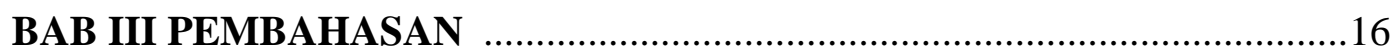

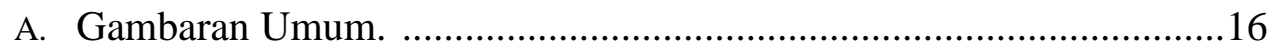

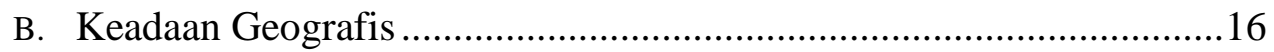

C. Jumlah penduduk 5 tahun terakhir beserta.......................................18

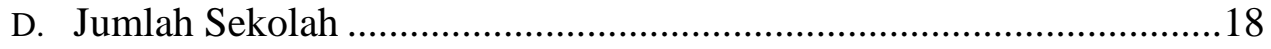

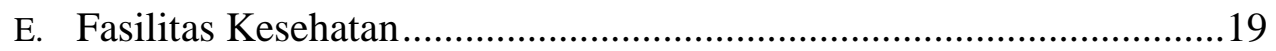

F. Fasilitas Perdagangan ................................................................ 19

G. Kebutuhan sarana dan prasarana Tahun $2025,2030,2035,2040$.........19

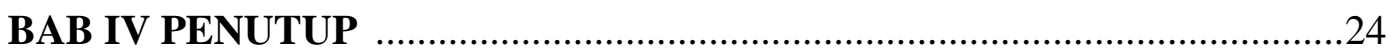

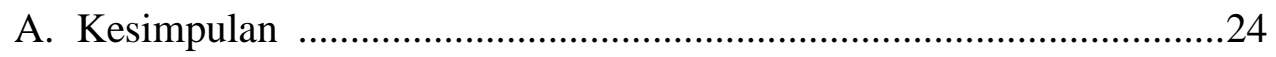

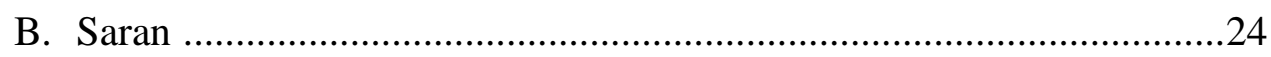

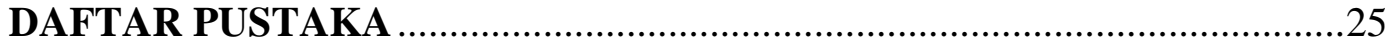




\section{DAFTAR TABEL}

Tabel 2.1. Kebutuhan Program Ruang Minimum................................. 4

Tabel 2.2. Kebutuhan Sarana Pendidikan dan Pembelajaran ............... 5

Tabel 2.3. Kebutuhan Sarana Kesehatan ......................................... 5

Tabel 2.4. Kebutuhan Sarana Peribadatan......................................... 6

Tabel 2.5. Jenis Sarana Perdaganagan dan Niaga ............................. 7

Tabel 2.6. Kebutuhan Sarana Kebudayaan dan Rekreasi.................... 7

Tabel 2.7. Sarana Ruang Terbuka, Taman dan Lapangan Olah raga... 8

Tabel 2.8. Bagian Jaringan Drainase ............................................. 10

Tabel 2.9. Kebutuhan Prasarana Persampahan ................................. 11

Tabel 2.10 Kebutuhan dan Persyaratan Jaringan Transportasi Lokal .. 15

Tabel 3.1 Jumlah Penduduk........................................................ 18

Tabel 3.2 Jumlah Sekolah.......................................................... 18

Tabel 3.3 Fasilitas Kesehatan....................................................... 19

Tabel $3.4 \quad$ Fasilitas Perdaganagan............................................. 19

Tabel 3.5 Kebutuhan Sarana Pendidikan Tahun 2024..................... 19

Tabel 3.6 Kebutuhan Sarana Pendidikan Tahun 2029 ...................... 20

Tabel 3.7 Kebutuhan Sarana Pendidikan Tahun 2034 ...................... 20

Tabel 3.8 Kebutuhan Sarana Pendidikan Tahun 2039 ...................... 20

Tabel 3.9 Kebutuhan Sarana Kesehatan Tahun 2024...................... 21

Tabel 3.10 Kebutuhan Sarana Kesehatan Tahun 2029...................... 21

Tabel 3.11 Kebutuhan Sarana Kesehatan Tahun 2034...................... 21 
Tabel 3.12 Kebutuhan Sarana Kesehatan Tahun 2039

Tabel 3.13 Kebutuhan Sarana Perdagangan tahun 2024................... 22

Tabel 3.14 Kebutuhan Sarana Perdagangan Tahun 2029 .................. 22

Tabel 3.15 Kebutuhan Sarana Perdagangan Tahun 2034 .................. 23

Tabel 3.16 Kebutuhan Sarana Perdagangan Tahun 2039 .................. 23 


\section{DAFTAR GAMBAR}

Gambar 3.1 Peta Administrasi Kecamatan Mangkutana ................... 40 


\begin{abstract}
Paper ini membahas bagaimana kebutuhan sarana dan prasarana di Kecamatan Mangkutana Kabupaten Luwu Timur. Fokus utamanya adalah sarana pendidikan, kesehatan dan perekonomian. Paper ini merupakan tugas mata kuliah Perencanaan Wilayah dan Kota.
\end{abstract}




\section{Bab I \\ Pendahuluan}

\subsection{Latar Belakang}

Sarana dan prasarana suatu wilayah merupakan salah satu aspek penting dalam kehidupan manusia. Dengan adanya sarana dan prasarana suatu wilayah, manusia dapat menjalankan aktifitas sehari-hari nya dengan lancar. Begitu juga bagi pemerintah, Sarana dan Prasarana merupakan hal terpenting untuk menjalankan roda ekonomi dan pemerintahan. Jika kondisi Sarana dan prasarana suatu wilayah baik, maka aktifitas perekonomian dan transportasi juga akan menjadi lancar. Oleh karena itu, pemerintah perlu mendata sarana dan prasarana yang ada diwilayah pemerintahannya. Hal ini dilakukan untuk mengetahui kondisi sarana dan prasarana beserta data atribut yang berhubungan dengan sarana dan prasarana tersebut.

Untuk memudahkan dalam pendataan dan pengolahan data sarana dan prasarana tersebut, dapat dilakukan dengan sebuah sistem yang berbasis komputer. Dengan adanya sebuah sistem informasi tersebut, data beserta peta sarana dan prasarana dapat diproses secara otomatis oleh komputer. Sistem informasi ini dirancang untuk proses mengumpulkan dan menyimpan data objek. Sistem informasi ini dapat mengintegrasikan data spasial (peta vektor dan citra digital), atribut (tabel basis data), dan lain sebagainya. Mengingat bahwa data yang diproses memiliki volume dan variasi yang banyak, sehingga memungkinkan terjadi tingginya tingkat kesalahan dan lambatnya pengolahan data, akibatnya informasi yang dihasilkan tidak akurat dan dapat memperlambat proses pengambilan keputusan serta sulit nya memperoleh data sarana dan prasaran suatu wilayah.

Pengertian sarana prasarana menurut ketentuan umum permendiknas (Peraturan Menteri Pendidikan Nasional) No. 24 Tahun 2007 yaitu sarana adalah segala sesuatu yang dapat dipakai sebagai alat dan bahan untuk mencapai maksud dan tujuan dari suatu proses produksi sedangkan prasarana ialah segala sesuatu yang dapat dipakai sebagai alat dan bahan untuk mencapai maksud dan tujuan dari suatu proses produksi. Dengan kata lain prasarana ditujukan untuk benda-benda yang tidak bergerak seperti gedung, jaringan drainase, jaringan listrik, dan jaringan telefon. Serta maksud dari sarana yaitu fasilitas untuk mencapai suatu tujuan yaitu 
kesejahteraan seperti sekolah, perkantoran, kesehatan maupun sarana pendukung aktifitas manusia yang lainya.

Pembangunan prasarana dan sarana ini juga telah diatur dalam UU Nomor 1 Tahun 2011 tentang Perumahan dan Kawasan Permukiman. Jumlah penduduk, proyeksi jumlah penduduk, dan pergerakan pertumbuhan penduduk sangat berpengaruh dalam pembangunan prasarana dan sarana baik perkotaan maupun perumahan.

Mangkutana adalah sebuah kecamatan di Kabupaten Luwu Timur, Sulawesi Selatan, Indonesia. Terdiri dari 8 desa dan berbatasan dengan Sulawesi Tengah di bagian utaranya, penduduk Mangkutana cukup majemuk, sebagai konsekuensi menjadi salah satu daerah transmigrasi di Luwu Timur. Mangkutana juga merupakan salah satu daerah yang dilalui jalan penghubung utama antara Sulawesi Selatan dengan Sulawesi Tengah. Bagian selatan kecamatan secara geografis datar, dan lahan yang luas ini banyak dijadikan persawahan atau pemukiman. Sementara itu, bagian utara yang berbatasan dengan Sulawesi Tengah merupakan daerah pegunungan, dan selain hutan yang lebat, lahan di bagian utara sebagiannya dimanfaatkan untuk perkebunan. Mangkutana termasuk salah satu kecamatan yang terbentuk sebelum Kabupaten Luwu Timur terbentuk. Kemudian, kecamatan ini dipecah menjadi dua, salah satunya menjadi kecamatan Kalaena.

\subsection{Rumusan Masalah}

1. Menghitung proyeksi penduduk yang ada di Mangkutana 5 tahun terakhir

2. Menghitung fasilitas sarana dan prasarana yang ada di Mangkutana

3. Menghitung proyeksi kebutuhan sarana dan prasarana yang ada di Mangkutana untuk 20 tahun yang akan datang

\subsection{Tujuan}

1. Agar mengetahui jumlah penduduk yang ada di Mangkutana 5 tahun terakhir

2. Agar mengetahui jumlah fasilitas sarana dan prasarana yang ada di Mangkutana

3. Agar mengetahui jumlah kebutuhan sarana dan prasarana yang ada di Mangkutana untuk 20 tahun yang akan datang 


\section{BAB II \\ LANDASAN TEORI}

\subsection{Definisi Sarana dan Prasarana}

Prasarana adalah kelengkapan dasar fisik suatu lingkungan, kawasan, kota atau wilayah (spatial space) sehingga memungkinkan ruang tersebut berfungsi sebagaimana mestinya. Infrastuktur metujuk pada sistem fisik yang menyediakan transportasi, pengairan, drainase, bangunan-bangunan gedung dan fasilitas publik yang lain yang dibutuhkan untuk memenuhi kebutuhan dasar manusia dalam lingkup sosial dan ekonomi (Grigg,1988 dalam Kodoatie,2005:8). Sementara itu adapun pengertian prasarana menurut Jayadinata (1992 dalam Juliawan,2015:5) prasarana merupakan suatu faktor potensial yang sangat penting dalam menentukan arah dan masa depan perkembangan suatu wilayah, karena pembangunan tidak akan sukses dan berjalandengan baik tanpa dukungan prasarana yang memadai, prasarana kota merupakan fasilitas umum yang menjadi penunjang utama terselenggaranya suatu proses atau kegiatan dalam kota yang pada akhirnya akan menentukan perkembangan kota. Dengan demikian prasarana kota merupakan fasilitas umum yang menjadi penunjang utama terselenggaranya suatu proses atau kegiatan dalam kota, yang padxa akhirnya akan menentukanperkembangan kota.

Prasarana lingkungan merupakan kelengkapan dasar fisik lingkungan yang memungkinkan lingkungan dapat berfungsi sebagaimana mestinya, lebih jelasnya prasarana lingkungan atau sarana yang utama bagi berfungsinya suatu lingkungan permukiman adalah jaringan jalan untuk mobilitas orang dan angkutan barang, mencegah perambatan kebakaran serta untuk menciptakan ruang dan bangunan yang teratur, jaringan air bersih, jaringan saluran pembuangan air limbah dan tempat pembuangan sampah untuk kesehatan lingkungan, serta jaringan saluran air hujan untuk pematusan (drainase) dan pencegah banjir setempat.

Fungsi prasarana adalah untuk melayani dan mendorong terwujudnya lingkungan permukiman dan lingkungan usaha yang optimal sesuai dengan fungsinya, upaya memperbaiki lingkungan membutuhkan keseimbangan antar tingkat kebutuhan masyarakat (Diwiryo,1996 dalam Juliawan, 2015:6) 
Dari pengertian tersebut dapat disederhanakan bahwa prasarana merupakan kerangka dasar dari suatu sistem, kerangka dasar tersebut menjadi fasilitas umum dan pelengkapan dasar fisik yang memungkinkan lingkungan untuk berfungsi sebagaimana mestinya, serta menjadi penentu keberhasilan dari suatu perkembangan kota.

\subsection{Standar Sarana dan Prasarana Wilayah}

\section{Sarana pendidikan dan pembelajaran}

Dasar penyediaan sarana pendidikan adalah untuk melayani setiap unit administrasi pemerintahan baik yang informal (RT, RW) maupun yang formal (Kelurahan, Kecamatan), dan bukan didasarkan semata-mata pada jumlah penduduk yang akan dilayani oleh sarana tersebut. Dasar penyediaan sarana pendidikan ini juga mempertimbangkan pendekatan desain keruangan unitunit atau kelompok lingkungan yang ada. Tentunya hal ini dapat terkait dengan bentukan grup bangunan/blok yang nantinya terbentuk sesuai konteks lingkungannya. Sedangkan penempatan penyediaan fasilitas ini akan mempertimbangkan jangkauan radius area layanan terkait dengan kebutuhan dasar sarana yang harus dipenuhi untuk melayani pada area tertentu.

Tabel 1:Kebutuhan program ruang minimum

\begin{tabular}{|c|c|c|}
\hline No. & Jenis Sarana & Program Ruang \\
\hline 1. & Taman Kanak- & Memiliki minimum 2 ruang kelas @ 25-30 \\
\hline 2. & Sekolah Dasar & \multirow{3}{*}{$\begin{array}{l}\text { Memiliki minimum } 6 \text { ruang kelas @ } 40 \text { murid } \\
\text { Dilengkapi dengan ruang-ruang lain dan ruang } \\
\text { terbuka / bermain } \pm 3000-7000 \mathrm{~m}^{2}\end{array}$} \\
\hline 3. & SLTP & \\
\hline 4. & SMU & \\
\hline 5. & Taman Bacaan & Memiliki minimum 1 ruang baca @ 15 murid \\
\hline
\end{tabular}

CATATAN : Acuan diambil dari SNI 03-1733-1989, Tata cara perencanaan kawasan perumahan kota 
Tabel 2:Kebutuhan sarana pendidikan dan pembelajaran

\begin{tabular}{|c|c|c|c|c|c|c|c|}
\hline \multirow[b]{2}{*}{ No. } & \multirow[b]{2}{*}{ Jenis Sarana } & \multirow{2}{*}{$\begin{array}{c}\text { Jumlah } \\
\text { Penduduk } \\
\text { pendukung } \\
\text { (jiwa) }\end{array}$} & \multicolumn{2}{|c|}{$\begin{array}{l}\text { Kebutuhan Per } \\
\text { Satuan Sarana }\end{array}$} & \multirow[b]{2}{*}{$\begin{array}{l}\text { Standard } \\
\left(\mathrm{m}^{2} / \text { jiwa) }\right.\end{array}$} & \multicolumn{2}{|c|}{ Kriteria } \\
\hline & & & $\begin{array}{l}\text { Luas } \\
\text { Lantail } \\
\text { Min. } \\
\left(m^{2}\right)\end{array}$ & $\begin{array}{l}\text { Luas } \\
\text { Lahan } \\
\text { Min. } \\
\left(\mathrm{m}^{2}\right)\end{array}$ & & $\begin{array}{c}\text { Radius } \\
\text { pencapaian }\end{array}$ & $\begin{array}{l}\text { Lokasi dan } \\
\text { Penyelesaian }\end{array}$ \\
\hline 1. & $\begin{array}{l}\text { Toko I } \\
\text { Warung }\end{array}$ & 250 & $\begin{array}{r}50 \\
\text { (termasuḱk } \\
\text { gudang) }\end{array}$ & $\begin{array}{r}100 \\
\text { (bila } \\
\text { berdiri } \\
\text { sendin) }\end{array}$ & $\overline{0,4}$ & $300 \mathrm{~m}^{\prime}$ & $\begin{array}{l}\text { Di tengah } \\
\text { kelompok tetangga. } \\
\text { Dapat merupakan } \\
\text { bagian dari sarana } \\
\text { lain }\end{array}$ \\
\hline 2. & Pertokoan & 6.000 & 1.200 & 3.000 & 0,5 & $2.000 \mathrm{~m}^{\prime}$ & $\begin{array}{l}\text { Di pusat kegiatan } \\
\text { sub lingkungan. } \\
\text { KDB 40\% Dapat } \\
\text { berbentuk P3D }\end{array}$ \\
\hline 3. & $\begin{array}{l}\text { Pusat } \\
\text { Pertokoan + } \\
\text { Pasar } \\
\text { Lingkungan }\end{array}$ & 30.000 & 13.500 & 10.000 & 0,33 & & $\begin{array}{l}\text { Dapat dijangkau } \\
\text { dengan kendaraan } \\
\text { umum }\end{array}$ \\
\hline 4. & $\begin{array}{l}\text { Pusat } \\
\text { Perbelanjaan } \\
\text { dan Niaga } \\
\text { (toko + pasar } \\
+ \text { bank + } \\
\text { kantor) }\end{array}$ & 120.000 & 36.000 & 36.000 & 0,3 & & $\begin{array}{l}\text { Terletak di jalan } \\
\text { utama. } \\
\text { Termasuk sarana } \\
\text { parkir sesuai } \\
\text { ketentuan } \\
\text { setempat }\end{array}$ \\
\hline
\end{tabular}

\section{Sarana kesehatan}

Berfungsi memberikan pelayanan kesehatan kesehatan kepada masyarakat, memiliki peran yang sangat strategis dalam mempercepat peningkatan derajat kesehatan masyarakat sekaligus untuk mengendalikan pertumbuhan penduduk. Dasar penyediaan sarana ini adalah didasarkan jumlah penduduk yang dilayani oleh sarana tersebut. Dasar penyediaan ini juga akan mempertimbangkan pendekatan desain keruangan unit-unit atau kelompok lingkungan yang ada.

Tabel 3:Kebutuhan sarana kesehatan

\begin{tabular}{|c|c|c|c|c|c|c|c|c|}
\hline \multirow[b]{2}{*}{ No. } & \multirow[b]{2}{*}{$\begin{array}{l}\text { Jenis } \\
\text { Sarana }\end{array}$} & \multirow{2}{*}{$\begin{array}{l}\text { Jumlah } \\
\text { Penduduk } \\
\text { pendukung } \\
\text { (jiwa) }\end{array}$} & \multicolumn{2}{|c|}{$\begin{array}{l}\text { Kebutuhan Per } \\
\text { Satuan Sarana }\end{array}$} & \multirow[b]{2}{*}{$\begin{array}{l}\text { Standard } \\
\left(\mathrm{m}^{2} \text { (p)wa) }\right.\end{array}$} & \multicolumn{2}{|c|}{ Kriteria } & \multirow[b]{2}{*}{ Keterangan } \\
\hline & & & $\begin{array}{l}\text { Luas } \\
\text { Lantai } \\
\text { Min. } \\
\left(\mathrm{m}^{\prime}\right)\end{array}$ & $\begin{array}{l}\text { Luas } \\
\text { Lahan } \\
\text { Min } \\
\left(\mathrm{m}^{2}\right)\end{array}$ & & $\begin{array}{c}\text { Radius } \\
\text { pencapaian }\end{array}$ & $\begin{array}{c}\text { Lokasi dan } \\
\text { Penyelesaian }\end{array}$ & \\
\hline 1. & Posyandu & 1.250 & 36 & 60 & 0,048 & 500 & $\begin{array}{l}\text { Di tengah ke- } \\
\text { lompok } \\
\text { tetangga tidak } \\
\text { menyeberang } \\
\text { jalan raya. }\end{array}$ & $\begin{array}{l}\text { Dapat berga- } \\
\text { bung dengan } \\
\text { balai warga } \\
\text { atau sarana } \\
\text { huniarviumah }\end{array}$ \\
\hline 2. & $\begin{array}{l}\text { Baiai } \\
\text { Pengabatan } \\
\text { Warga }\end{array}$ & 2.500 & 150 & 300 & 0,12 & $1.000 \mathrm{~m}^{\prime}$ & $\begin{array}{l}\text { Di lengah } \\
\text { keiompok } \\
\text { tetanoga tidak } \\
\text { menyeberang } \\
\text { jaian raya. }\end{array}$ & $\begin{array}{l}\text { Dapat } \\
\text { bergabung } \\
\text { dalam lokasi } \\
\text { balai warga }\end{array}$ \\
\hline 3. & $\begin{array}{l}\text { BXiA / Klinik } \\
\text { Bersalin }\end{array}$ & 30.000 & 1.500 & 3.000 & 0,1 & $4.000 \mathrm{~m}$ & $\begin{array}{l}\text { Dapat } \\
\text { dijargkau } \\
\text { dengan } \\
\text { kendaraan } \\
\text { umum }\end{array}$ & \\
\hline 4. & $\begin{array}{l}\text { Puskesmas } \\
\text { Pembantu } \\
\text { dan Baiai } \\
\text { Pengobatan } \\
\text { Lingkungan }\end{array}$ & 30.000 & 150 & 300 & 0,006 & $1.500 \mathrm{~m}$ & -idem- & $\begin{array}{l}\text { Dapat berg- } \\
\text { bung dalam } \\
\text { lokasi kantor } \\
\text { kelurahan }\end{array}$ \\
\hline 5. & $\begin{array}{l}\text { Puskesmas } \\
\text { dan Balai } \\
\text { Pengobatan }\end{array}$ & 120.000 & 420 & 1.000 & 0,008 & $3.000 \mathrm{~m}$ & idem- & $\begin{array}{l}\text { Dapat } \\
\text { bergabung } \\
\text { dalam lokasi } \\
\text { kartor } \\
\text { kecamatan }\end{array}$ \\
\hline 6. & $\begin{array}{l}\text { Tempat } \\
\text { Praktek } \\
\text { Dokter }\end{array}$ & 5.000 & 18 & - & - & $1.500 \mathrm{~m}^{\prime}$ & -idem- & $\begin{array}{l}\text { Dapat bersatu } \\
\text { dengan rumah } \\
\text { tingpa/tempat }\end{array}$ \\
\hline 7. & $\begin{array}{l}\text { Apotik / } \\
\text { Rumah } \\
\text { Obat }\end{array}$ & 30.000 & 120 & 250 & 0,025 & $1.500 \mathrm{~m}$ & -idem- & usaha'apotik \\
\hline
\end{tabular}


CATATAN : Acuan diambil dari SNI 03-1733-1989, Tata cara perencanaan kawasan perumahan kota.

\section{Sarana Peribadatan}

Merupakan sarana kehidupan untuk mengisi kebutuhan rohani yang perlu disediakan di lingkungan perumahan yang direncanakan selain sesuai peraturan yang ditetapkan, juga sesuai dengan keputusan masyarakat yang bersangkutan. Oleh karena berbagai macam agama dan kepercayaan yang dianut oleh masyarakat penghuni yang bersangkutan, maka kepastian tentang jenis dan jumlah fasilitas peribadatan yang akan dibangun baru dapat dipastikan setelah lingkungan perumahan dihuni selama beberapa waktu.

Tabel 4:Kebutuhan sarana peribadatan

\begin{tabular}{|c|c|c|c|c|c|c|c|}
\hline \multirow[b]{2}{*}{ No. } & \multirow[b]{2}{*}{ Jenis Sarana } & \multirow{2}{*}{$\begin{array}{c}\text { Jumlah } \\
\text { Penduduk } \\
\text { pendukung } \\
\text { (jiwa) }\end{array}$} & \multicolumn{2}{|c|}{$\begin{array}{l}\text { Kebutuhan Per } \\
\text { Satuan Sarana }\end{array}$} & \multirow[b]{2}{*}{$\begin{array}{l}\text { Standard } \\
\left(\mathrm{m}^{2} / \text { jiwa }\right)\end{array}$} & \multicolumn{2}{|c|}{ Kriteria } \\
\hline & & & $\begin{array}{l}\text { Luas } \\
\text { Lantai } \\
\text { Min. } \\
\left(\mathrm{m}^{2}\right)\end{array}$ & $\begin{array}{l}\text { Luas } \\
\text { Lahan } \\
\text { Min. } \\
\left(\mathrm{m}^{2}\right)\end{array}$ & & $\begin{array}{c}\text { Radius } \\
\text { pencapaian }\end{array}$ & $\begin{array}{l}\text { Lokasi dan } \\
\text { Penyelesaian }\end{array}$ \\
\hline 1. & $\begin{array}{l}\text { Toko I } \\
\text { Warung }\end{array}$ & 250 & $\begin{array}{r}50 \\
\text { (termasuk } \\
\text { gudang) }\end{array}$ & $\begin{array}{r}100 \\
\text { (bila } \\
\text { berdiri } \\
\text { sendiri) }\end{array}$ & $\overline{0,4}$ & $300 \mathrm{~m}^{\prime}$ & $\begin{array}{l}\text { Di tengah } \\
\text { kelompok tetangga. } \\
\text { Dapat merupakan } \\
\text { bagian dari sarana } \\
\text { lain }\end{array}$ \\
\hline 2. & Pertokoan & 6.000 & 1.200 & 3.000 & 0,5 & $2.000 \mathrm{~m}^{\prime}$ & $\begin{array}{l}\text { Di pusat kegiatan } \\
\text { sub lingkungan. } \\
\text { KDB } 40 \% \text { Dapat } \\
\text { berbentuk P\&D }\end{array}$ \\
\hline 3. & $\begin{array}{l}\text { Pusat } \\
\text { Pertokoan + } \\
\text { Pasar } \\
\text { Lingkungan }\end{array}$ & 30.000 & 13.500 & 10.000 & 0,33 & & $\begin{array}{l}\text { Dapat dijangkau } \\
\text { dengan kendaraan } \\
\text { umum }\end{array}$ \\
\hline 4. & $\begin{array}{l}\text { Pusat } \\
\text { Perbelanjaan } \\
\text { dan Niaga } \\
\text { (toko + pasar } \\
+ \text { bank + } \\
\text { kantor) } \\
\end{array}$ & 120.000 & 36.000 & 36.000 & 0,3 & & $\begin{array}{l}\text { Terletak di jalan } \\
\text { utama. } \\
\text { Termasuk sarana } \\
\text { parkir sesuai } \\
\text { ketentuan } \\
\text { setempat }\end{array}$ \\
\hline
\end{tabular}

CATATAN : Acuan diambil dari Kota SNI 03-1733-1989, tentang Tata cara perencanaan kawasan perumahan kota

\section{Sarana perdagangan dan niaga}

Yaitu sektor yang tidak selalu berdiri sendiri dan terpisah dengan bangunan sarana yang lain. Dasar penyediaan selain berdasarkan jumlah penduduk yang akan dilayaninya, juga mempertimbangkan pendekatan desain keruangan unit-unit atau kelompok lingkungan yang ada. Tentunya hal ini dapat terkait dengan bentukan grup bangunan / blok yang nantinya terbentuk sesuai konteks lingkungannya. Sedangkan penempatan penyediaan fasilitas ini akan mempertimbangkan jangkauan radius area layanan terkait dengan kebutuhan dasar sarana yang harus dipenuhi untuk melayani pada area tertentu. 
Tabel 5:Jenis sarana perdagangan dan niaga

\begin{tabular}{|c|c|c|c|c|c|c|c|}
\hline \multirow[b]{2}{*}{ No. } & \multirow[b]{2}{*}{ Jenis Sarana } & \multirow{2}{*}{$\begin{array}{l}\text { Jumlah } \\
\text { Penduduk } \\
\text { pendukung } \\
\text { (jiwa) }\end{array}$} & \multicolumn{2}{|c|}{$\begin{array}{l}\text { Kebutuhan Per } \\
\text { Satuan Sarana }\end{array}$} & \multirow[b]{2}{*}{$\begin{array}{l}\text { Standard } \\
\left(\mathrm{m}^{2} / \text { jiwa }\right)\end{array}$} & \multicolumn{2}{|c|}{ Kriteria } \\
\hline & & & $\begin{array}{l}\text { Luas } \\
\text { Lantai } \\
\text { Min. } \\
\left(\mathrm{m}^{2}\right)\end{array}$ & $\begin{array}{l}\text { Luas } \\
\text { Lahan } \\
\text { Min. } \\
\left(\mathrm{m}^{2}\right) \\
\end{array}$ & & $\begin{array}{c}\text { Radius } \\
\text { pencapaian }\end{array}$ & $\begin{array}{l}\text { Lokasi dan } \\
\text { Penyelesaian }\end{array}$ \\
\hline$\overline{1 .}$ & $\begin{array}{l}\text { Toko I } \\
\text { Warung }\end{array}$ & 250 & $\begin{array}{r}50 \\
\text { (termasuk } \\
\text { gudang) }\end{array}$ & $\begin{array}{r}100 \\
\text { (bila } \\
\text { berdiri } \\
\text { sendin) }\end{array}$ & $\overline{0,4}$ & $300 \mathrm{~m}^{\prime}$ & $\begin{array}{l}\text { Di tengah } \\
\text { kelompok tetangga, } \\
\text { Dapat merupakan } \\
\text { bagian dari sarana } \\
\text { lain }\end{array}$ \\
\hline 2. & Pertokoan & 6.000 & 1.200 & 3.000 & 0,5 & $2.000 \mathrm{~m}$ & $\begin{array}{l}\text { Di pusat kegiatan } \\
\text { sub lingkungan. } \\
\text { KDB } 40 \% \text { Dapat } \\
\text { berbentuk P\&D }\end{array}$ \\
\hline 3. & $\begin{array}{l}\text { Pusat } \\
\text { Pertokoan + } \\
\text { Pasar } \\
\text { Lingkungan }\end{array}$ & 30.000 & 13.500 & 10.000 & 0,33 & & $\begin{array}{l}\text { Dapat dijangikau } \\
\text { dengan kendaraan } \\
\text { umum }\end{array}$ \\
\hline 4. & $\begin{array}{l}\text { Pusat } \\
\text { Perbelanjaan } \\
\text { dan Niaga } \\
\text { (toko + pasar } \\
\text { + bank + } \\
\text { kantor) }\end{array}$ & 120.000 & 36.000 & 36.000 & 0,3 & & $\begin{array}{l}\text { Terletak di jalan } \\
\text { utama. } \\
\text { Termasuk sarana } \\
\text { parkir sesuai } \\
\text { ketentuan } \\
\text { setempat }\end{array}$ \\
\hline
\end{tabular}

CATATAN : Acuan diambil dari SNI 03-1733-1989, Tata cara perencanaan kawasan perumahan kota

\section{Sarana kebudayaan dan rekreasi}

Merupakan bangunan yang dipergunakan untuk mewadahi berbagai kegiatan kebudayaan dan atau rekreasi, seperti gedung pertemuan, gedung serba guna, bioskop, gedung kesenian, dan lain-lain. Bangunan dapat sekaligus berfungsi sebagai bangunan sarana pemerintahan dan pelayanan umum, sehingga penggunaan dan pengelolaan bangunan ini dapat berintegrasi menurut kepentingannya pada waktu-waktu yang berbeda.

\section{Tabel 6:Kebutuhan sarana kebudayaan dan rekreasi}

\begin{tabular}{|c|c|c|c|c|c|c|c|}
\hline \multirow[b]{2}{*}{ No. } & \multirow[b]{2}{*}{ Jenis Sarana } & \multirow{2}{*}{$\begin{array}{c}\text { Jumlah } \\
\text { Penduduk } \\
\text { pendukung } \\
\text { (jiwa) }\end{array}$} & \multicolumn{2}{|c|}{$\begin{array}{l}\text { Kebutuhan Per } \\
\text { Satuan Sarana }\end{array}$} & \multirow[b]{2}{*}{$\begin{array}{l}\text { Standard } \\
\left(m^{2} / j \text { iwa }\right)\end{array}$} & \multicolumn{2}{|c|}{ Kriteria } \\
\hline & & & $\begin{array}{l}\text { Luas } \\
\text { Lantai } \\
\text { Min. } \\
\left(\mathrm{m}^{2}\right) \\
\end{array}$ & $\begin{array}{l}\text { Luas } \\
\text { Lahan } \\
\text { Min. } \\
\left(\mathrm{m}^{2}\right) \\
\end{array}$ & & $\begin{array}{c}\text { Radius } \\
\text { pencapaian }\end{array}$ & $\begin{array}{l}\text { Lokasi dan } \\
\text { Penyelesaian }\end{array}$ \\
\hline 1. & $\begin{array}{l}\text { Balai Warga/ } \\
\text { Balai } \\
\text { Pertemuan }\end{array}$ & 2.500 & 150 & 300 & 0,12 & $100 \mathrm{~m}^{\prime}$ & $\begin{array}{l}\text { Di tengah kelompok } \\
\text { tetangga. } \\
\text { Dapat menupakan } \\
\text { bagian dari bangunan } \\
\text { sarana lain }\end{array}$ \\
\hline 2. & $\begin{array}{l}\text { Balai } \\
\text { Serbaguna I } \\
\text { Balai Karang } \\
\text { Taruna }\end{array}$ & 30.000 & 250 & 500 & 0,017 & $100 \mathrm{~m}$ & Di pusat lingkungan. \\
\hline 3. & $\begin{array}{l}\text { Gedung } \\
\text { Serbaguna }\end{array}$ & 120.000 & 1.500 & 3.000 & 0,025 & $100 \mathrm{~m}^{\prime}$ & $\begin{array}{l}\text { Dapat dijangkau } \\
\text { dengan kendaraan } \\
\text { umum }\end{array}$ \\
\hline 4. & $\begin{array}{l}\text { Gedung } \\
\text { Bioskop }\end{array}$ & 120.000 & 1.000 & 2.000 & 0,017 & $100 \mathrm{~m}^{\prime}$ & $\begin{array}{l}\text { Terletak di jalan } \\
\text { utama. } \\
\text { Dapat merupakan } \\
\text { bagian dari pusat } \\
\text { perbelanjaan }\end{array}$ \\
\hline
\end{tabular}

CATATAN : Acuan diambil dari SNI 03-1733-1989, Tata cara perencanaan kawasan perumahan kota 


\section{Sarana ruang terbuka, taman dan lapangan olah raga}

Merupakan komponen berwawasan lingkungan, yang mempunyai arti sebagai suatu lansekap, hardscape, taman atau ruang rekreasi dalam lingkup urban. Peran dan fungsi Ruang Terbuka Hijau (RTH) di tetapkan dalam Instruksi Mendagri no. 4 tahun 1988, yang menyatakan "Ruang terbuka hijau yang populasinya di dominasi oleh penghijauan baik secara alamiah atau budi daya tanaman, dalam pemanfataan dan fungsinya adalah sebagai areal berlangsungnya fungsi ekologis dan penyangga kehidupan wilayah perkotaan.

Tabel 7:Sarana Terbuka, Taman dan Lapangan Olah Raga

\begin{tabular}{|c|c|c|c|c|c|c|}
\hline No. & Jenis Sarana & $\begin{array}{l}\text { Jumiah } \\
\text { Penduduk } \\
\text { pendukung } \\
\text { (jiwa) }\end{array}$ & $\begin{array}{l}\text { Kebutuhan } \\
\text { Luas } \\
\text { Lahan Min. } \\
\left(\mathrm{m}^{2}\right)\end{array}$ & $\begin{array}{l}\text { Standard } \\
\left(\mathrm{m}^{2} / \mathrm{j} \text { wa) }\right.\end{array}$ & $\begin{array}{c}\text { Radius } \\
\text { pencapaian } \\
\text { (m) }\end{array}$ & $\begin{array}{c}\text { Kriteria } \\
\text { Lokasi dan Penyelesaian }\end{array}$ \\
\hline 1. & $\begin{array}{l}\text { Taman } \\
\text { Trempat Main }\end{array}$ & 250 & 250 & $\overline{1}$ & 100 & $\begin{array}{l}\text { Di tengah kelompok } \\
\text { tetangga. }\end{array}$ \\
\hline 2. & $\begin{array}{l}\text { Taman/ } \\
\text { Tempat Main }\end{array}$ & 2.500 & 1.250 & 0,5 & 1.000 & Di pusat kegiatan lingkungan. \\
\hline 3. & $\begin{array}{l}\text { Taman dan } \\
\text { Lapangan } \\
\text { Olah Raga }\end{array}$ & 30.000 & 9.000 & 0,3 & & $\begin{array}{l}\text { Sedapat mungkin berkelompk } \\
\text { dengan sarana pendidikan. }\end{array}$ \\
\hline 4. & $\begin{array}{l}\text { Taman dan } \\
\text { Lapangan } \\
\text { Olah Raga }\end{array}$ & 120.000 & 24.000 & 0,2 & & $\begin{array}{l}\text { Terletak di jalan utama. } \\
\text { Sedapat mungkin } \\
\text { berkelompok dengan sarana } \\
\text { pendidikan. }\end{array}$ \\
\hline 5. & Jalur Hijau & $\cdot$ & $\cdot$ & $15 \mathrm{~m}$ & & Terletak menyebar. \\
\hline 6. & $\begin{array}{l}\text { Kuburan I } \\
\text { Pemakaman } \\
\text { Umum }\end{array}$ & 120.000 & & & & $\begin{array}{l}\text { Mempertimbangkan radius } \\
\text { pencapaian dan area yang } \\
\text { dilayani. }\end{array}$ \\
\hline
\end{tabular}

CATATAN : Acuan tabel diambil dari SNI 03-1733-1989, tentang Tata cara perencanaan kawasan perumahan kota.

\section{Prasarana Lingkungan}

Adalah kelengkapan dasar fisik lingkungan yang memungkinkan lingkungan permukiman dapat berfungsi sebagaimana mestinnya.

\section{Sarana Lingkungan}

Adalah fasilitas penunjang, yang berfungsi untuk menyelenggarakan dan mengembangkan kehidupan ekonomi, social dan budaya.

\section{Jalan}

Adalah prasarana transportasi darat yang meliputi segala bagian jalan, termasuk bangunan pelengkap dan perlengkapannya yang diperuntukkan bagi lalu lintas, yang berada pada permukaan tanah, di atas permukaan tanah, di bawah permukaan tanah dan/atau air, serta di atas permukaan air, kecuali jalan 
kereta api, jalan lori, dan jalan kabel. Pengertian Jalan menurut SNI adalah jalur yang direncanakan atau digunakan untuk lalu lintas kendaraan dan orang.

> Jalan arteri, merupakan jalan umum yang berfungsi melayani angkutan utama dengan ciri perjalanan jarak jauh, kecepatan rata-rata tinggi, dan jumlah jalan masuk (akses) dibatasi secara berdaya guna.

> Jalan Kolektor yaitu jalur selebar \pm m yang melayani angkutan pengumpulan/pembagian dengan ciri-ciri perjalanan jarak sedang, kecepatan rata-rata sedangdan jumlah jalan masuk dibatasi.

> Jalan Lokal yaitu jalur yang melayani angkutan setempat dengan ciri-ciri perjalanan dekat, kecepatan rata-rata rendah, dan jumlah jalan masuk dibatasi

- Jalan Lokal Sekunder jalur selebar $\pm 3,0 \mathrm{~m}-7,0 \mathrm{~m}$ yang merupakan jalan poros perumahan menubungkan jalan arteri /kolektor/lokal dan pusat lingkungan permukiman.

- Jalan Lokal Sekunder II dan III jalur selebar $\pm 3,0 \mathrm{~m}-6,0 \mathrm{~m}$ penghubung jalan arteri /kolektor/lokaldengan pusat kegiatan lingkungan permukiman, menuju akses yang lebihh tinggi hirarkinya

Jalan Lingkungan yaitu jalur selebar \pm 4 m yang ada dalam satuan permukiman atau lingkungan perumahan

- Jalan Lingkungan I jalur selebar $\pm 1,5 \mathrm{~m}-2,0 \mathrm{~m}$ penghubung pusat permukiman dengn pusat lingkungan I dengan pusat lingkungan I yang lainnya; atau menuju lokal sekunder III.

\section{Jaringan Drainase}

Drainase atau pengatusan adalah pembuangan massa air secara alami atau buatan dari permukaan atau bawah permukaan dari suatu tempat. Pembuangan ini dapat dilakukan dengan mengalirkan, menguras, membuang, atau mengalihkan air. Irigasi dan drainase merupakan bagian penting dalam penataan sistem penyediaan air di bidang pertanian maupun tata ruang. Pengertian Drainase menurut SNI adalah prasarana yang berfungsi mengalirkan air permukaan ke badan penerima air dan atau ke bangunan 
resapan buatan, yang harus disediakan pada lingkungan perumahan di perkotaan.

Tabel 8:Bagian jaringan drainase

\begin{tabular}{|l|l|}
\cline { 2 - 2 } Sarana & Prasarana \\
\hline Badan penerima air & Sumber air di permukaan tanah (laut, sungai, danau) \\
\cline { 2 - 2 } & $\begin{array}{l}\text { Sumber air di bawah permukaan tanah (air tanah } \\
\text { akifer) }\end{array}$ \\
\hline Bangunan pelengkap & Gorong-gorong \\
\cline { 2 - 2 } & Pertemuan saluran \\
\cline { 2 - 2 } & Bangunan terjunan \\
\hline & Jembatan \\
\hline & Street inlet \\
\hline & Pompa \\
\hline & Pintu air \\
\hline
\end{tabular}

\section{Jaringan Air Bersih}

Setiap rumah harus dapat dilayani air bersih yang memenuhi persyaratan untuk keperluan rumah tangga.

$\checkmark$ Penyediaan jaringan air bersih

1. Harus tersedia jaringan kota atau lingkungan sampai dengan sambungan rumah

2. Pipa yang ditanam dalam tanah menggunakan pipa PVC, GIP atau fiber glass; dan 3) pipa yang dipasang di atas tanah tanpa perlindungan menggunakan GIP.

$\checkmark$ Penyediaan kran umum

1. Satu kran umum disediakan untuk jumlah pemakai 250 jiwa

2. Radius pelayanan maksimum 100 meter

3. kapasitas minimum untuk kran umum adalah 30 liter/orang/hari; dan

4. ukuran dan konstruksi kran umum sesuai dengan SNI 03-2399-1991 tentang Tata Cara Perencanaan Bangunan MCK Umum.

$\checkmark$ Penyediaan hidran kebakaran

a) untuk daerah komersial jarak antara kran kebakaran 100 meter

b) untuk daerah perumahan jarak antara kran maksimum 200 meter

c) jarak dengan tepi jalan minimum 3.00 meter 
d) apabila tidak dimungkinkan membuat kran diharuskan membuat sumursumur kebakaran; dan

e) perencanaan hidran kebakaran mengacu pada SNI 03-1745-1989 tentang Tata Cara Pemasangan Sistem Hidran Untuk Pencegahan Bahaya Kebakaran Pada Bangunan Rumah dan Gedung

\section{Jaringan Persampahan}

Untuk mengangkut sampah-sampah masyarakat yang ada di daerah tersebut dari TPS menuju TPA.

Tabel 9:Kebutuhan prasarana persampahan

\begin{tabular}{|c|c|c|c|c|c|}
\hline \multirow{2}{*}{$\begin{array}{c}\text { Lingkup } \\
\text { Prasarana }\end{array}$} & \multicolumn{3}{|c|}{ Prasarana } & \multirow{2}{*}{\multicolumn{2}{|c|}{ Keterangan }} \\
\hline & $\begin{array}{c}\text { Sarana } \\
\text { pelengkap }\end{array}$ & Status & Dimensi & & \\
\hline $\begin{array}{l}\text { Rumah } \\
\text { (5 jiwa) }\end{array}$ & $\begin{array}{c}\text { Tong } \\
\text { sampah }\end{array}$ & Pribadi & - & \multicolumn{2}{|c|}{--} \\
\hline \multirow{3}{*}{$\begin{array}{c}\text { RW } \\
(2500 \\
\text { jiwa) }\end{array}$} & $\begin{array}{c}\text { Gerobak } \\
\text { sampah }\end{array}$ & \multirow{3}{*}{ TPS } & $2 \mathrm{~m}^{3}$ & \multirow{7}{*}{$\begin{array}{c}\text { Jarak } \\
\text { bebas } \\
\text { TPS } \\
\text { dengan } \\
\text { lingkung } \\
\text { an } \\
\text { hunian } \\
\text { minimal } \\
\text { 30m }\end{array}$} & Gerobak \\
\hline & $\begin{array}{c}\text { Bak sampah } \\
\text { kecil }\end{array}$ & & $6 \mathrm{~m}^{3}$ & & ut \\
\hline & & & & & $\begin{array}{c}3 \mathrm{x} \\
\text { seminggu }\end{array}$ \\
\hline \multirow{2}{*}{$\begin{array}{c}\text { Keluraha } \\
\text { n } \\
(\mathbf{3 0 . 0 0 0} \\
\text { jiwa) }\end{array}$} & $\begin{array}{c}\text { Gerobak } \\
\text { sampah }\end{array}$ & \multirow[b]{2}{*}{ TPS } & $2 \mathrm{~m}^{3}$ & & \multirow{2}{*}{$\begin{array}{c}\text { Gerobak } \\
\text { mengangk } \\
\text { ut } \\
3 x \\
\text { seminggu }\end{array}$} \\
\hline & $\begin{array}{c}\text { Bak sampah } \\
\text { besar }\end{array}$ & & $12 \mathrm{~m}^{3}$ & & \\
\hline \multirow{2}{*}{$\begin{array}{c}\text { Kecamata } \\
\text { n } \\
(\mathbf{1 2 0 . 0 0 0} \\
\text { jiwa) }\end{array}$} & $\begin{array}{c}\text { Mobil } \\
\text { sampah }\end{array}$ & \multirow[b]{2}{*}{$\begin{array}{c}\text { TPS/TPA } \\
\text { lokal }\end{array}$} & - & & \multirow{2}{*}{$\begin{array}{c}\text { Mobil } \\
\text { mengangk } \\
\text { ut } \\
3 \mathrm{x} \\
\text { seminggu }\end{array}$} \\
\hline & $\begin{array}{c}\text { Bak sampah } \\
\text { besar }\end{array}$ & & $25 \mathrm{~m}^{3}$ & & \\
\hline$\underset{(>}{\text { Kota }}$ & $\begin{array}{c}\text { Bak sampah } \\
\text { akhir }\end{array}$ & TPA & - & & - \\
\hline
\end{tabular}




\begin{tabular}{|c|c|l|l|l|}
\hline $\begin{array}{c}\text { 480.000 } \\
\text { jiwa) }\end{array}$ & $\begin{array}{c}\text { Tempat daur } \\
\text { ulang }\end{array}$ & & - & \\
& sampah & & & \\
& & & \\
\hline
\end{tabular}

\section{Jaringan Listrik}

Dari sekian banyak bentuk energi yang ada, energi listrik lah yang paling banyak dimanfaatkan oleh manusia, hal tersebut dikarenakan energi listrik sangat mudah diubah menjadi bentuk energi yang lain, sehingga hanya dengan memanfaatkan energi listrik maka kebutuhan energi yang lain akan dapat terpenuhi, selain itu energi listrik juga dapat disimpan dan digunakan sewaktuwaktu sesuai kebutuhan jadi akan lebih hemat. Mengingat kebutuhan masyarakat akan listrik yang begitu besar, maka sesuai dengan UUD 1945 yang menyatakan bahwa "aset yang menyangkut harkat hidup orang banyak dikuasai oleh negara" pemerintah mengambil alih pengelolaan listrik yang ada di Indonesia dalam sebuah Perusahaan Listrik Negara (PLN). PLN berkewajiban menyuplai listrik untuk kemudian dimanfaatkan sebesar-besarnya untuk kepentingan masyarakat dan negara. Dalam upaya terlaksananya pembangunan yang merata maka PLN bertugas untuk mendistribusikan listrik dari sumber pembangkit listrik ke daerah-daerah lain yang membutuhkan. Pengertian listrik menurut SNI yaitu Lingkungan perumahan harus dilengkapi perencanaan penyediaan jaringan listrik sesuai ketentuan dan persyaratan teknis.

$\checkmark$ Penyediaan kebutuhan daya listrik

1. setiap lingkungan perumahan harus mendapatkan daya listrik dari PLN atau dari sumber lain; dan

2. setiap unit rumah tangga harus dapat dilayani daya listrik minimum 450 VA per jiwa dan untuk sarana lingkungan sebesar $40 \%$ dari total kebutuhan rumah tangga.

$\checkmark$ Penyediaan jaringan listrik

1) Disediakan jaringan listrik lingkungan dengan mengikuti hirarki pelayanan, dimana besar pasokannya telah diprediksikan berdasarkan jumlah unit hunian yang mengisi blok siap bangun; 
2) Disediakan tiang listrik sebagai penerangan jalan yang ditempatkan pada area damija (daerah milik jalan) pada sisi jalur hijau yang tidak menghalangi sirkulasi pejalan kaki di trotoar (lihat Gambar 1 mengenai bagian-bagian pada jalan);

3) Disediakan gardu listrik untuk setiap 200 KVA daya listrik yang ditempatkan pada lahan yang bebas dari kegiatan umum;

4) Adapun penerangan jalan dengan memiliki kuat penerangan 500 lux dengan tinggi > 5 meter dari muka tanah;

5) Sedangkan untuk daerah di bawah tegangan tinggi sebaiknya tidak dimanfaatkan untuk tempat tinggal atau kegiatan lain yang bersifat permanen karena akan membahayakan keselamatan;

\section{Jaringan Telepon}

Lingkungan perumahan harus dilengkapi jaringan telepon sesuai ketentuan dan persyaratan teknis yang diatur dalam peraturan / perundangan yang telah berlaku, terutama mengenai tata cara perencanaan umum jaringan telepon lingkungan perumahan di perkotaan.

$\checkmark$ Penyediaan kebutuhan sambungan telepon

1. Tiap lingkungan rumah perlu dilayani sambungan telepon rumah dan telepon umum sejumlah 0,13 sambungan telepon rumah per jiwa atau dengan menggunakan asumsi berdasarkan tipe rumah sebagai berikut:

- R-1, rumah tangga berpenghasilan tinggi : 2-3 sambungan/rumah

- R-2, rumah tangga berpenghasilan menengah : 1-2 sambungan/rumah

- R-3, rumah tangga berpenghasilan rendah : 0-1 sambungan/rumah

2. Dibutuhkan sekurang-kurangnya 1 sambungan telepon umum untuk setiap 250 jiwa penduduk (unit RT) yang ditempatkan pada pusat-pusat kegiatan lingkungan RT tersebut;

3. Ketersediaan antar sambungan telepon umum ini harus memiliki jarak radius bagi pejalan kaki yaitu 200 - 400 m;

4. Penempatan pesawat telepon umum diutamakan di area-area publik seperti ruang terbuka umum, pusat lingkungan, ataupun berdekatan dengan bangunan sarana lingkungan; dan 
5. Penempatan pesawat telepon harus terlindungi terhadap cuaca (hujan dan panas matahari) yang dapat diintegrasikan dengan kebutuhan kenyamanan pemakai telepon umum tersebut.

$\checkmark$ Penyediaan jaringan telepon

1. Tiap lingkungan rumah perlu dilayani jaringan telepon lingkungan dan jaringan telepon ke hunian;

2. Jaringan telepon ini dapat diintegrasikan dengan jaringan pergerakan (jaringan jalan) dan jaringan prasarana / utilitas lain;

3. Tiang listrik yang ditempatkan pada area Damija $(\approx$ daerah milik jalan, lihat Gambar 1 mengenai bagian-bagian pada jalan) pada sisi jalur hijau yang tidak menghalangi sirkulasi pejalan kaki di trotoar; dan

4. Stasiun telepon otomat (STO) untuk setiap 3.000 - 10.000 sambungan dengan radius pelayanan $3-5 \mathrm{~km}$ dihitung dari copper center, yang berfungsi sebagai pusat pengendali jaringan dan tempat pengaduan pelanggan.

\section{Jaringan Transportasi Lokal}

Lingkungan perumahan direkomendasikan untuk dilalui sarana jaringan transportasi lokal atau memiliki akses yang tidak terlampau jauh (maksimum 1 $\mathrm{km})$ menuju sarana transportasi tersebut. Lingkungan perumahan harus dilengkapi jaringan transportasi sesuai ketentuan dan persyaratan teknis yang diatur dalam peraturan / perundangan yang telah berlaku, terutama mengenai tata cara perencanaan umum jaringan transportasi lingkungan perumahan di perkotaan. 
Tabel 10:Kebutuhan dan persyaratan jaringan transportasi lokal

\begin{tabular}{|c|c|c|c|c|c|c|c|}
\hline \multirow[b]{2}{*}{ No. } & \multirow[b]{2}{*}{ Jenis Sarana } & \multirow{2}{*}{$\begin{array}{c}\text { Jumlah } \\
\text { Penduduk } \\
\text { pendukung } \\
\text { (jiwa) }\end{array}$} & \multicolumn{2}{|c|}{$\begin{array}{l}\text { Kebutuhan Per } \\
\text { Satuan Sarana }\end{array}$} & \multirow[b]{2}{*}{$\begin{array}{l}\text { Standard } \\
\left(\mathrm{m}^{2} / \text { jiwa }\right)\end{array}$} & \multicolumn{2}{|c|}{ Kriteria } \\
\hline & & & $\begin{array}{l}\text { Luas } \\
\text { Lantai } \\
\text { Min. } \\
\left(\mathrm{m}^{2}\right) \\
\end{array}$ & $\begin{array}{l}\text { Luas } \\
\text { Lahan } \\
\text { Min. } \\
\left(\mathrm{m}^{2}\right) \\
\end{array}$ & & $\begin{array}{c}\text { Radius } \\
\text { pencapaian }\end{array}$ & $\begin{array}{l}\text { Lokasi dan } \\
\text { Penyelesaian }\end{array}$ \\
\hline 1. & $\begin{array}{l}\text { Toko I } \\
\text { Warung }\end{array}$ & 250 & $\begin{array}{r}50 \\
\text { (termasuk } \\
\text { gudang) }\end{array}$ & $\begin{array}{r}100 \\
\text { (bila } \\
\text { berdiri } \\
\text { sendiri) }\end{array}$ & 0,4 & $300 \mathrm{~m}^{\prime}$ & $\begin{array}{l}\text { Di tengah } \\
\text { kelompok tetangga. } \\
\text { Dapat merupakan } \\
\text { bagian dari sarana } \\
\text { lain }\end{array}$ \\
\hline 2. & Pertokoan & 6.000 & 1.200 & 3.000 & 0,5 & $2.000 \mathrm{~m}^{\mathrm{r}}$ & $\begin{array}{l}\text { Di pusat kegiatan } \\
\text { sub lingkungan. } \\
\text { KDB } 40 \% \text { Dapat } \\
\text { berbentuk P\&D }\end{array}$ \\
\hline 3. & $\begin{array}{l}\text { Pusat } \\
\text { Pertokoan + } \\
\text { Pasar } \\
\text { Lingkungan }\end{array}$ & 30.000 & 13.500 & 10.000 & 0,33 & & $\begin{array}{l}\text { Dapat dijangkau } \\
\text { dengan kendaraan } \\
\text { umum }\end{array}$ \\
\hline 4. & $\begin{array}{l}\text { Pusat } \\
\text { Perbelanjaan } \\
\text { dan Niaga } \\
\text { (toko + pasar } \\
\text { + bank + } \\
\text { kantor) }\end{array}$ & 120.000 & 36.000 & 36.000 & 0,3 & & $\begin{array}{l}\text { Terletak di jalan } \\
\text { utama. } \\
\text { Termasuk sarana } \\
\text { parkir sesuai } \\
\text { ketentuan } \\
\text { setempat }\end{array}$ \\
\hline
\end{tabular}




\section{BAB III \\ PEMBAHASAN}

\section{A. GAMBARAN UMUM}

\section{PETA ADMINISTRASI KECAMATAN MANGKUTANA}

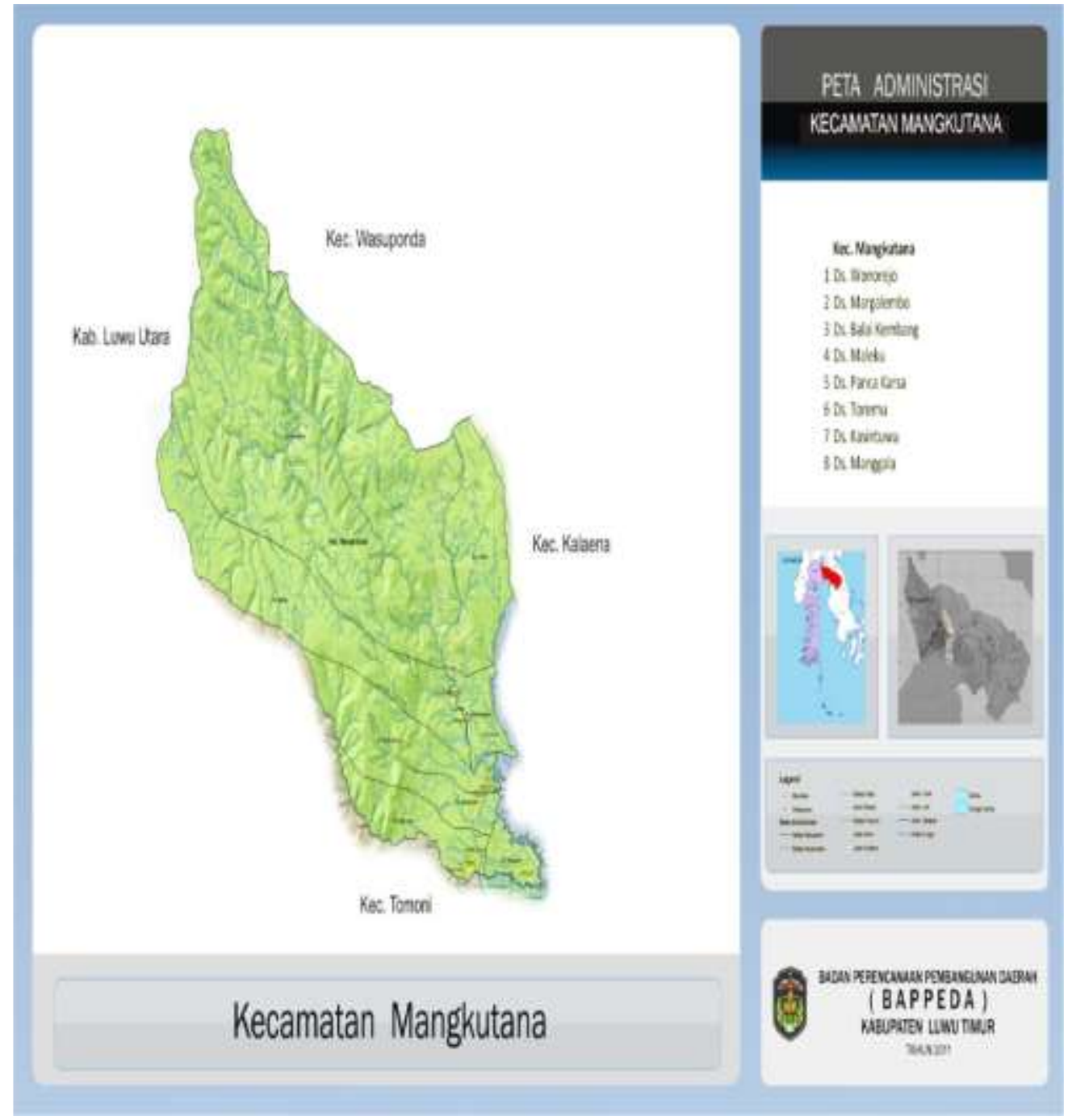

\section{B. KEADAAN GEOGRAFIS}

Kecamatan Mangkutana merupakan salah satu Kecamatan di Kabupaten

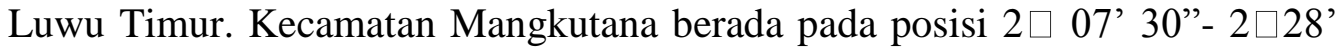
30"Lintang Selatan dan 120 $\square 31$ '30" - 120 $\square 52$ ' 30" Bujur Timur dengan Luas Wilayah 1.300,96 km2. Kecamatan yang terletak di sebelah Barat ibu Kota Kabupaten Luwu Timur ini berbatasan langsung dengan Propinsi Sulawesi 
Tengah di sebelah Utara, Kecamatan Wasuponda dan Kalaena di sebelah Timur,Kecamatan Tomoni dan Tomoni Timur di sebelah Selatan, dan di sebelah Barat berbatasan dengan Kabupaten Luwu Utara. Kecamatan Mangkutana terdiri dari 11 Desa yang seluruhnya berstatus Desa Definitif yaitu: Desa Balai kembang, Manggala, Wonorejo, Maleku, Panca Karsa, Margolembo, Kasintuwu, Teromu,Wonorejo Timur, Sindu Agung dan Koroncia. Desa yang memiliki wilayah terluas di kecamatan ini adalah Desa Kasintuwu dengan luas $679.48 \mathrm{~km} 2$, sedangkan desa dengan wilayah terkecil adalah Desa Wonorejo Timur dengan luas wilayah $6,10 \mathrm{~km} 2$. Wilayah kecamatan Mangkutana merupakan wilayah bukan pantai dengan topografi dataran dan hanya Desa Kasintuwu dan Margolembo yang topografinya berbukit-bukit. Ada tiga sungai yang melintasi kecamatan ini yaitu Sungai Waelanti yang melintas di Desa Kasintuwu, Sungai Kalaena melintas di Desa Teromu dan Morgolembo, dan Sungai Tomoni yang melintasi Desa Balai kembang, Wonorejo, Maleku dan Manggala. Jumlah hujan di Kecamatan Mangkutana paling banyak terjadi pada bulan April dengan jumlah 25 hari dan curah hujan tinggi sebesar $660.5 \mathrm{~mm}$. Rata -rata curah hujan secara keseluruhan untuk Kecamatan Mangkutana pada tahun 2019 adalah sebesar 292 mm, dengan rata rata hari hujan sebanyak 14 hari/bulan.

Mangkutana adalah sebuah kecamatan di Kabupaten Luwu Timur, Sulawesi Selatan, Indonesia. Terdiri dari 8 desa dan berbatasan dengan Sulawesi Tengah di bagian utaranya, penduduk Mangkutana cukup majemuk, sebagai konsekuensi menjadi salah satu daerah transmigrasi di Luwu Timur. Mangkutana juga merupakan salah satu daerah yang dilalui jalan penghubung utama antara Sulawesi Selatan dengan Sulawesi Tengah.

Bagian selatan kecamatan secara geografis datar, dan lahan yang luas ini banyak dijadikan persawahan atau pemukiman. Sementara itu, bagian utara yang berbatasan dengan Sulawesi Tengah merupakan daerah pegunungan, dan selain hutan yang lebat, lahan di bagian utara sebagiannya dimanfaatkan untuk perkebunan.

Mangkutana termasuk salah satu kecamatan yang terbentuk sebelum Kabupaten Luwu Timur terbentuk. Kemudian, kecamatan ini dipecah menjadi dua, salah satunya menjadi kecamatan Kalaena. 
C. JUMLAH PENDUDUK

\begin{tabular}{|c|l|c|c|c|c|c|}
\hline No & Desa/Kelurahan & $\mathbf{2 0 1 5}$ & $\mathbf{2 0 1 6}$ & $\mathbf{2 0 1 7}$ & $\mathbf{2 0 1 8}$ & $\mathbf{2 0 1 9}$ \\
\hline 1 & Balai Kembang & 1920 & 1923 & 1902 & 1894 & 1942 \\
\hline 2 & Manggala & 892 & 873 & 854 & 852 & 901 \\
\hline 3 & Wonorejo & 2164 & 2208 & 2237 & 2212 & 2551 \\
\hline 4 & Maleku & 2613 & 2749 & 2577 & 2743 & 2805 \\
\hline 5 & Panca Karsa & 1609 & 1607 & 1637 & 1615 & 1617 \\
\hline 6 & Margolembo & 2734 & 2784 & 2649 & 2607 & 2679 \\
\hline 7 & Kasintuwu & 3170 & 3173 & 3150 & 3060 & 3290 \\
\hline 8 & Teromu & 1536 & 1612 & 1613 & 1619 & 1609 \\
\hline 9 & Wonorejo Timur & 2276 & 2266 & 2220 & 2255 & 2550 \\
\hline 10 & Sindu Agung & 1787 & 1776 & 1822 & 1821 & 1833 \\
\hline 11 & Koroncia & 999 & 987 & 975 & 972 & 746 \\
\hline & Jumlah & 21700 & 21959 & 21636 & 21650 & 22523 \\
\hline
\end{tabular}

D. JUMLAH SEKOLAH

\begin{tabular}{|c|l|c|c|c|c|c|}
\hline No & \multicolumn{1}{|c|}{ Tingkat Pendidikan } & $\mathbf{2 0 1 5}$ & $\mathbf{2 0 1 6}$ & $\mathbf{2 0 1 7}$ & $\mathbf{2 0 1 8}$ & $\mathbf{2 0 1 9}$ \\
\hline 1 & Taman Kanak (TK) & 15 & 15 & 15 & 15 & 15 \\
\hline 2 & Sekolah Dasar (SD) & 16 & 16 & 16 & 16 & 16 \\
\hline 3 & $\begin{array}{l}\text { Sekolah Menengah Pertama } \\
\text { (SMP) }\end{array}$ & 3 & 3 & 3 & 3 & 3 \\
\hline 4 & Sekolah Menengah Atas (SMA) & 3 & 3 & 3 & 3 & 3 \\
\hline \multicolumn{2}{|c|}{ Jumlah } & 37 & 37 & 37 & 37 & 37 \\
\hline
\end{tabular}


E. FASILITAS KESEHATAN

\begin{tabular}{|c|l|c|c|c|c|c|}
\hline No & Fasilitas Kesehatan & $\mathbf{2 0 1 5}$ & $\mathbf{2 0 1 6}$ & $\mathbf{2 0 1 7}$ & $\mathbf{2 0 1 8}$ & $\mathbf{2 0 1 9}$ \\
\hline 1 & Pustu & 6 & 6 & 6 & 6 & 6 \\
\hline 2 & Puskesmas & 1 & 1 & 1 & 1 & 1 \\
\hline 3 & Rumah Sakit & - & - & - & - & - \\
\hline 4 & Posyandu & 26 & 26 & 26 & 26 & 26 \\
\hline 5 & Tokoh Obat & - & - & - & - & 2 \\
\hline \multicolumn{2}{|c|}{ Jumlah } & 35 & 35 & 35 & 35 & 35 \\
\hline
\end{tabular}

\section{F. FASILITAS PERDAGANGAN}

\begin{tabular}{|c|l|c|c|c|c|c|}
\hline No & Fasiltas Perdagangan & $\mathbf{2 0 1 5}$ & $\mathbf{2 0 1 6}$ & $\mathbf{2 0 1 7}$ & $\mathbf{2 0 1 8}$ & $\mathbf{2 0 1 9}$ \\
\hline 1 & Kios & - & - & - & - & 281 \\
\hline 2 & Warung & - & - & - & - & 150 \\
\hline 3 & Pasar Jumlah & 5 & 5 & 5 & 4 & 4 \\
\hline \multicolumn{2}{|c|}{} & 5 & 5 & 5 & 4 & 435 \\
\hline
\end{tabular}

\section{G. KEBUTUHAN SARANA DAN PRASARANA TAHUN 2024,2029,2034 dan 2039}

1) Sarana Pendidikan

- Tahun 2024

\begin{tabular}{|c|c|c|c|c|c|c|}
\hline No & $\begin{array}{c}\text { Sarana } \\
\text { Pendidikan }\end{array}$ & $\begin{array}{c}\text { Jumlah } \\
\text { Penduduk } \\
\text { Tahun } \\
2024\end{array}$ & $\begin{array}{c}\text { Jumlah } \\
\text { Sarana } \\
\text { Pendidikan }\end{array}$ & $\begin{array}{c}\text { Jumlah } \\
\text { Penduduk } \\
\text { Pendukung }\end{array}$ & $\begin{array}{c}\text { Kebutuhan } \\
\text { Berdasarkan } \\
\text { SNI }\end{array}$ & Penambahan \\
\hline 1 & TK & & 15 & 1.250 & 18 & 3 \\
\hline 2 & SD & \multirow{2}{*}{23.595} & 16 & 2.000 & 11 & 5 \\
\cline { 5 - 7 } 3 & SMP & 3 & 4.800 & 4 & 1 \\
\hline 4 & SMA & & 3 & 4.800 & 4 & 1 \\
\hline
\end{tabular}


- Tahun 2029

\begin{tabular}{|c|c|c|c|c|c|c|}
\hline No & $\begin{array}{c}\text { Sarana } \\
\text { Pendidikan }\end{array}$ & $\begin{array}{c}\text { Jumlah } \\
\text { Penduduk } \\
\text { Tahun } \\
2029\end{array}$ & $\begin{array}{c}\text { Jumlah } \\
\text { Sarana } \\
\text { Pendidikan }\end{array}$ & $\begin{array}{c}\text { Jumlah } \\
\text { Penduduk } \\
\text { Pendukung }\end{array}$ & $\begin{array}{c}\text { Kebutuhan } \\
\text { Berdasarkan } \\
\text { SNI }\end{array}$ & Penambahan \\
\hline 1 & TK & & 15 & 1.250 & 19 & 4 \\
\cline { 1 - 4 } 2 & SD & \multirow{2}{*}{24.719} & 16 & 2.000 & 12 & 4 \\
\cline { 5 - 7 } 3 & SMP & 3 & 4.800 & 5 & 2 \\
\hline 4 & SMA & & 3 & 4.800 & 5 & 2 \\
\cline { 5 - 6 } & & & & & \\
\hline
\end{tabular}

- Tahun 2034

\begin{tabular}{|c|c|c|c|c|c|c|}
\hline No & $\begin{array}{c}\text { Sarana } \\
\text { Pendidikan }\end{array}$ & $\begin{array}{c}\text { Jumlah } \\
\text { Penduduk } \\
\text { Tahun } \\
2034\end{array}$ & $\begin{array}{c}\text { Jumlah } \\
\text { Sarana } \\
\text { Pendidikan }\end{array}$ & $\begin{array}{c}\text { Jumlah } \\
\text { Penduduk } \\
\text { Pendukung }\end{array}$ & $\begin{array}{c}\text { Kebutuhan } \\
\text { Berdasarkan } \\
\text { SNI }\end{array}$ & Penambahan \\
\hline 1 & TK & & 15 & 1.250 & 20 & 5 \\
\hline 2 & SD & \multirow{2}{*}{25.897} & 16 & 2.000 & 12 & 4 \\
\cline { 5 - 7 } 3 & SMP & 3 & 4.800 & 5 & 2 \\
\hline 4 & SMA & & 3 & 4.800 & 5 & 2 \\
\cline { 5 - 6 } & & & & & \\
\hline
\end{tabular}

- Tahun 2039

\begin{tabular}{|c|c|c|c|c|c|c|}
\hline No & $\begin{array}{c}\text { Sarana } \\
\text { Pendidikan }\end{array}$ & $\begin{array}{c}\text { Jumlah } \\
\text { Penduduk } \\
\text { Tahun } \\
2039\end{array}$ & $\begin{array}{c}\text { Jumlah } \\
\text { Sarana } \\
\text { Pendidikan }\end{array}$ & $\begin{array}{c}\text { Jumlah } \\
\text { Penduduk } \\
\text { Pendukung }\end{array}$ & $\begin{array}{c}\text { Kebutuhan } \\
\text { Berdasarkan } \\
\text { SNI }\end{array}$ & Penambahan \\
\hline 1 & TK & & 15 & 1.250 & 21 & 6 \\
\hline 2 & SD & \multirow{2}{*}{27.130} & 16 & 2.000 & 13 & 3 \\
\cline { 5 - 7 } 3 & SMP & 3 & 4.800 & 5 & 2 \\
\hline 4 & SMA & & 3 & 4.800 & 5 & 2 \\
\cline { 5 - 6 } & & & & & \\
\hline
\end{tabular}


2) Sarana Kesehatan

- Tahun 2024

\begin{tabular}{|c|c|c|c|c|c|c|}
\hline No & $\begin{array}{c}\text { Sarana } \\
\text { Kesehatan }\end{array}$ & $\begin{array}{l}\text { Jumlah } \\
\text { Penduduk } \\
\text { Tahun } \\
2024\end{array}$ & $\begin{array}{c}\text { Jumlah } \\
\text { Sarana } \\
\text { Kesehatan }\end{array}$ & $\begin{array}{c}\text { Jumlah } \\
\text { Penduduk } \\
\text { Pendukung }\end{array}$ & $\begin{array}{c}\text { Kebutuhan } \\
\text { Berdasarkan } \\
\text { SNI }\end{array}$ & Penambahan \\
\hline 1 & Pustu & \multirow{5}{*}{23.595} & 6 & 1.250 & 18 & 12 \\
\hline 2 & Puskesmas & & 1 & 120.000 & 0 & - \\
\hline 3 & $\begin{array}{c}\text { Rumah } \\
\text { Sakit }\end{array}$ & & 0 & 120.000 & 0 & - \\
\hline 4 & Posyandu & & 26 & 1.250 & 18 & - \\
\hline 5 & Toko Obat & & 2 & 30.000 & 0 & - \\
\hline
\end{tabular}

- Tahun 2029

\begin{tabular}{|c|c|c|c|c|c|c|}
\hline No & $\begin{array}{c}\text { Sarana } \\
\text { Kesehatan }\end{array}$ & $\begin{array}{l}\text { Jumlah } \\
\text { Penduduk } \\
\text { Tahun } \\
2029 \\
\end{array}$ & $\begin{array}{c}\text { Jumlah } \\
\text { Sarana } \\
\text { Kesehatan }\end{array}$ & $\begin{array}{c}\text { Jumlah } \\
\text { Penduduk } \\
\text { Pendukung }\end{array}$ & $\begin{array}{c}\text { Kebutuhan } \\
\text { Berdasarkan } \\
\text { SNI }\end{array}$ & Penambahan \\
\hline 1 & Pustu & \multirow{5}{*}{24.719} & 6 & 1.250 & 19 & 13 \\
\hline 2 & Puskesmas & & 1 & 120.000 & 0 & - \\
\hline 3 & $\begin{array}{c}\text { Rumah } \\
\text { Sakit }\end{array}$ & & 0 & 120.000 & 0 & - \\
\hline 4 & Posyandu & & 26 & 1.250 & 19 & - \\
\hline 5 & Toko Obat & & 2 & 30.000 & 0 & - \\
\hline
\end{tabular}

- Tahun 2034

\begin{tabular}{|c|c|c|c|c|c|c|}
\hline No & $\begin{array}{c}\text { Sarana } \\
\text { Kesehatan }\end{array}$ & $\begin{array}{l}\text { Jumlah } \\
\text { Penduduk } \\
\text { Tahun } \\
2034\end{array}$ & $\begin{array}{c}\text { Jumlah } \\
\text { Sarana } \\
\text { Kesehatan }\end{array}$ & $\begin{array}{c}\text { Jumlah } \\
\text { Penduduk } \\
\text { Pendukung }\end{array}$ & $\begin{array}{c}\text { Kebutuhan } \\
\text { Berdasarkan } \\
\text { SNI }\end{array}$ & Penambahan \\
\hline 1 & Pustu & \multirow{5}{*}{25.897} & 6 & 1.250 & 20 & 14 \\
\hline 2 & Puskesmas & & 1 & 120.000 & 0 & - \\
\hline 3 & $\begin{array}{c}\text { Rumah } \\
\text { Sakit }\end{array}$ & & 0 & 120.000 & 0 & - \\
\hline 4 & Posyandu & & 26 & 1.250 & 20 & - \\
\hline 5 & Toko Obat & & 2 & 30.000 & 0 & - \\
\hline
\end{tabular}


- Tahun 2039

\begin{tabular}{|c|c|c|c|c|c|c|}
\hline No & $\begin{array}{c}\text { Sarana } \\
\text { Kesehatan }\end{array}$ & $\begin{array}{l}\text { Jumlah } \\
\text { Penduduk } \\
\text { Tahun } \\
2039\end{array}$ & $\begin{array}{c}\text { Jumlah } \\
\text { Sarana } \\
\text { Kesehatan }\end{array}$ & $\begin{array}{c}\text { Jumlah } \\
\text { Penduduk } \\
\text { Pendukung }\end{array}$ & $\begin{array}{c}\text { Kebutuhan } \\
\text { Berdasarkan } \\
\text { SNI }\end{array}$ & Penambahan \\
\hline 1 & Pustu & \multirow{5}{*}{27.130} & 6 & 1.250 & 21 & 15 \\
\hline 2 & Puskesmas & & 1 & 120.000 & 0 & - \\
\hline 3 & $\begin{array}{c}\text { Rumah } \\
\text { Sakit }\end{array}$ & & 0 & 120.000 & 0 & - \\
\hline 4 & Posyandu & & 26 & 1.250 & 21 & - \\
\hline 5 & Toko Obat & & 2 & 30.000 & 0 & - \\
\hline
\end{tabular}

3) Sarana Perdagangan

- Tahun 2024

\begin{tabular}{|c|c|c|c|c|c|c|}
\hline No & $\begin{array}{c}\text { Sarana } \\
\text { Pendidikan }\end{array}$ & $\begin{array}{c}\text { Jumlah } \\
\text { Penduduk } \\
\text { Tahun } \\
2024 \\
\end{array}$ & $\begin{array}{c}\text { Jumlah } \\
\text { Sarana } \\
\text { Perdagangan }\end{array}$ & $\begin{array}{c}\text { Jumlah } \\
\text { Penduduk } \\
\text { Pendukung }\end{array}$ & $\begin{array}{c}\text { Kebutuhan } \\
\text { Berdasarkan } \\
\text { SNI }\end{array}$ & Penambahan \\
\hline 1 & Kios & \multirow{3}{*}{23.595} & 281 & 250 & 0 & - \\
\hline 2 & Warung & & 150 & 250 & 0 & - \\
\hline 3 & Pasar & & 4 & 30.000 & 0 & - \\
\hline
\end{tabular}

- Tahun 2029

\begin{tabular}{|c|c|c|c|c|c|c|}
\hline No & $\begin{array}{c}\text { Sarana } \\
\text { Pendidikan }\end{array}$ & $\begin{array}{l}\text { Jumlah } \\
\text { Penduduk } \\
\text { Tahun } \\
2029\end{array}$ & $\begin{array}{c}\text { Jumlah } \\
\text { Sarana } \\
\text { Perdagangan }\end{array}$ & $\begin{array}{c}\text { Jumlah } \\
\text { Penduduk } \\
\text { Pendukung }\end{array}$ & $\begin{array}{c}\text { Kebutuhan } \\
\text { Berdasarkan } \\
\text { SNI }\end{array}$ & Penambahan \\
\hline 1 & Kios & \multirow{3}{*}{24.719} & 281 & 250 & 0 & - \\
\hline 2 & Warung & & 150 & 250 & 0 & - \\
\hline 3 & Pasar & & 4 & 30.000 & 0 & - \\
\hline
\end{tabular}


- Tahun 2034

\begin{tabular}{|c|c|c|c|c|c|c|}
\hline No & $\begin{array}{c}\text { Sarana } \\
\text { Pendidikan }\end{array}$ & $\begin{array}{c}\text { Jumlah } \\
\text { Penduduk } \\
\text { Tahun } \\
2034\end{array}$ & $\begin{array}{c}\text { Jumlah } \\
\text { Sarana } \\
\text { Perdagangan }\end{array}$ & $\begin{array}{c}\text { Jumlah } \\
\text { Penduduk } \\
\text { Pendukung }\end{array}$ & $\begin{array}{c}\text { Kebutuhan } \\
\text { Berdasarkan } \\
\text { SNI }\end{array}$ & Penambahan \\
\hline 1 & Kios & & 281 & 250 & 0 & - \\
\cline { 1 - 4 } 2 & Warung & \multirow{2}{*}{25.897} & 150 & 250 & 0 & - \\
\cline { 1 - 4 } 3 & Pasar & & 4 & 30.000 & 0 & - \\
\cline { 5 - 7 } & & & & & 0 \\
\hline
\end{tabular}

- Tahun 2039

\begin{tabular}{|c|c|c|c|c|c|c|}
\hline No & $\begin{array}{c}\text { Sarana } \\
\text { Pendidikan }\end{array}$ & $\begin{array}{l}\text { Jumlah } \\
\text { Penduduk } \\
\text { Tahun } \\
2039 \\
\end{array}$ & $\begin{array}{c}\text { Jumlah } \\
\text { Sarana } \\
\text { Perdagangan }\end{array}$ & $\begin{array}{c}\text { Jumlah } \\
\text { Penduduk } \\
\text { Pendukung }\end{array}$ & $\begin{array}{c}\text { Kebutuhan } \\
\text { Berdasarkan } \\
\text { SNI }\end{array}$ & Penambahan \\
\hline 1 & Kios & \multirow{3}{*}{27.130} & 281 & 250 & 0 & - \\
\hline 2 & Warung & & 150 & 250 & 0 & - \\
\hline 3 & Pasar & & 4 & 30.000 & 0 & - \\
\hline
\end{tabular}




\section{BAB IV}

\section{PENUTUP}

A. KESIMPULAN

1.) Jumlah penduduk untuk 20 tahun kedepan mengalami peningkatan.

2.) Ketersediaan sarana kesehatan atau fasilitas kesehatan 5 tahun terakhir belum ada perubahan atau penambahan

3.) Ketersediaan sarana pendidikan atau fasilitas pendidikan 5 tahun terakhir belum ada perubahan atau penambahan

B. SARAN

1.) Di kecamatan Mangkutana khususnya daerah dekat perbatasan Sulawesi Tengah cukup jauh untuk menempuh perjalanan ke puskesmas atau rumah sakit. Perlu adanya perhatian dari pemerintah untuk penambahan sarana kesehatan.

2.) Untuk proyeksi 20 tahun kedepan perlu adanya penambahan fasilitas perdagangan seperti pasar rakyat di Desa Kasintuwu karena jarak tempuh ke pasar induk (pasar heterogen) cukup jauh. 


\section{DAFTAR PUSTAKA}

SNI 03-1733-1989

Fisu, A. A., \& Didiharyono, D. (2020, April). Economic \& Financial Feasibility Analysis of Tarakan Fishery Industrial Estate Masterplan. In IOP Conference Series: Earth and Environmental Science (Vol. 469, No. 1, p. 012002). IOP Publishing.

Fisu, A. A., \& Marzaman, L. U. (2018). Pemetaan Partisipatif Kampung Pesisir Kelurahan Tallo Kota Makassar. To Maega: Jurnal Pengabdian Masyarakat, 1(1), 22-28.

https://luwutimurkab.bps.go.id/publication/2020/09/28/8696d9fd1037302364bbc6 ca/kecamatan-mangkutana-dalam-angka-2020.html

https://prasaranadansaranabesusutengah.blogspot.com/2016/06/prasarana-dansarana-wilayah-kota.html

https://nawasis.org/portal/digilib/read/sni-03-1733-2004-tata-cara-perencanaanlingkungan-perumahan-di-perkotaan/51450

Darma. 2003. Pengelolaan Sarana dan Prasarana. Jakarta. Gramedia.

Fauzi, Imron. 2008. Administrasi Sarana dan Prasarana. Imronfauzi.wordpress.com

Suryadi, 2002. Sarana dan Prasarana Pendidikan. Jakarta: Gramedia.

https://samplingkuliah.blogspot.com/2017/04/manajemen-sarana-dan-prasarana.html https://jurnalimprovement.wordpress.com/2016/07/13/perencanaan-pengadaansarana-dan-prasarana-pendidikan/ diakses pada tanggal 10 april 2019)

http://fip.um.ac.id/wp-content/uploads/2015/12/7 Pemeliharaan-Sarpras.pdf 
